\title{
USE OF BEEKEEPING AS A SOURCE OF INCOME FOR SMALL PRODUCERS
}

\author{
UTILIZAÇÃO DA APICULTURA COMO FONTE DE RENDA PARA PEQUENOS \\ PRODUTORES
}

\author{
Janaina Tayna Silva ${ }^{1}$ \\ Camila Ferreira de Souza² \\ Murilo Matias lima² \\ Bruna Matias de Souza Rocha² \\ Willian da Silva Gouvea² \\ Andrea Maria de Araujo Gabriel ${ }^{3}$ \\ Euclides Reuter de Oliveira ${ }^{3}$ \\ Jefferson Rodrigues Gandra ${ }^{3}$ \\ Orlando Filipe Costa Marques ${ }^{4}$ \\ Natalie Ferreira Neves ${ }^{4}$ \\ Hellén Felicidade Durães ${ }^{5}$
}

\begin{abstract}
The focus of this work was directed to bee management techniques, for honey production, that was appropriate for the success of the activity in the Areias, Santa Rosa, Itamarati, Santa Olga, Amparo and Quilombola settlements, located in Nioaque, Itaquirai, Ponta Porã, Nova Andradina, Dourados, respectively, all in Mato Grosso do Sul. With this activity, it was intended to the self-sufficiency of settlers, for the future, through honey production, to achieve food improvement and also income generation and income. During the action, several activities related to techniques and good practices in bee breeding were developed monthly. The monitoring and achievement of programmed objectives were performed by professionals in the area. After closing each step on the production scale, those involved were gathered to evaluate the activities. Thus, it was observed that the orientations, through theoretical and practical explanations, and the accompaniment offered to the settlers regarding the most adequate bee breeding presented positive results. Thus it can be concluded that honey production is a very appropriate activity for the community, incurring low costs, proving to be a good option for income generation in the countryside, where the merit of the activity is in the way everything was structured, with broad participation by beekeepers, well-organized groups, and the institutions they support.
\end{abstract}

Keywords: Family farming; Apis mellifera; Rural settlement; handling.

RESUMO: O enfoque deste trabalho foi direcionado para as técnicas de manejo com abelhas, para a produção do mel, que fossem apropriadas para o êxito da atividade nos

\footnotetext{
${ }^{1}$ Mestranda em Zootecnia - Produção animal pela Universidade Federal da Grande Dourados - UFGD.

2 Discente do Curso de Zootecnia, da FCA - Faculdade de Ciências Agrarias, UFGD - Universidade da Grande Grande Dourados.

${ }^{3}$ Docente da Faculdade de Ciências Agrárias/FCA na Universidade Federal da Grande Dourados, UFGD.

${ }^{4}$ Discente de pós-graduação em Produção animal da Faculdade de Ciências Agrárias/FCA na Universidade Federal da Grande Dourados, UFGD.

${ }^{5}$ Discente em Zootecnia pela Universidade Estadual de Montes Claros-Unimontes
}

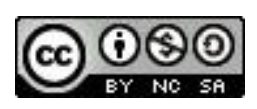


assentamentos Areias, Santa Rosa, Itamarati, Santa Olga, Amparo e Quilombola, situados nos municípios de Nioaque, Itaquirai, Ponta Porã, Nova Andradina, Dourados, respectivamente, todos no estado de Mato Grosso do Sul. Com essa atividade, pretendeuse à autossuficiência dos assentados, para futuramente, por meio da produção de mel, alcançar melhoria alimentar e também geração de receita e renda. Durante a ação foram desenvolvidas, mensalmente, várias atividades relacionadas as técnicas e boas práticas na criação de abelhas. O acompanhamento e o alcance dos objetivos programados foram realizados por profissionais da área. Após encerramento de cada etapa na escala de produção, os envolvidos foram reunidos para avaliar as atividades. Assim observou-se que as orientações, por meio de explanações teóricas e práticas, e os acompanhamentos oferecidos aos assentados quanto à criação mais adequada de abelhas apresentaram resultados positivos. Pôde-se concluir que a produção de mel é uma atividade apropriada aos comunitários, incorrendo em poucos custos, mostrando-se como uma boa opção para a geração de renda no campo, onde o mérito da atividade está na forma como tudo foi estruturado, com ampla participação dos apicultores, grupo bem organizado, e das instituições que apoiam.

Palavras-chave: Agricultura familiar; Apis mellifera; Assentamentos rurais; Manejo.

\section{INTRODUCTION}

The diversification of production systems is essential for maintaining and increasing income in rural properties, especially in family farming. In this context, beekeeping stands out as a productive activity in expansion, presenting itself as an alternative of exploration in small rural properties, attending to the tripod of sustainability (ecological, social, and economic).

Beekeeping comprises an area in wide expansion in the country. One of the characteristics that have favored its growth concerns the favorable condition for the creation of these insects, found in all Brazilian regions. Also, beekeeping does not require daily care, allowing beekeepers to combine this activity with others, making beekeeping an alternative source of income (VIEIRA et al., 2004)

Beekeeping is an alternative activity that adapts well to the Midwest Region, due to the vegetation of the cerrado that blooms successively from January to November (SANCHEZ, 1997). It is an activity considered conservative of species, being one of the few agricultural activities that are self-sustainable and can be developed in areas of legal reserves, thus taking advantage of the high diversity of existing plant species (BLUM and OLIVEIRA, 2003), and generating income for the farmer. 
World beekeeping represents an important source of occupation in the vast majority of developing countries, being carried out in relatively small family apiaries, where the family labor component represents an important input for the activity (MUNGUIA, 1998), requiring a low initial investment, stimulating the fixation of men in the field (OLIVEIRA et al., 2012).

As beekeeping can be combined with other activities, many beekeepers find this activity an alternative source of income. One of the main products obtained by beekeeping is honey. This product is a food and its importance is not limited to the sweetening characteristic, where it can be substituted by refined sugar from sugar cane; it must be considered as high-quality food, rich in energy and countless other beneficial substances to the balance of the biological processes of the organism, highlighting amino acids, enzymes, vitamins and phenolic substances (CAMARGO et al., 2006; SILVA et al., 2006).

One of the main obstacles encountered by small farmers is the lack of adequate technical knowledge to intensify the activity. In this scenario, the rural extension comes as an alternative to develop and enhance the beekeeping activity in small rural properties seeking to promote the economic, social, cultural development and management capacity of the rural producer, through lectures and technical visits (KRONEMBERGER and GUEDES, 2014 ).

Based on the above, the study objective was, through extension activities, to guide and encourage family farmers in several municipalities in the state of Mato Grosso do Sul, to develop beekeeping as an alternative source of income.

\section{MATERIAL AND METHODS}

The activities were developed through extension projects in the Areias, Santa Rosa, Itamarati, Santa Olga, Amparo and Quilombola settlements located in the city of Nioaque, Itaquirai, Ponta Porã, Nova Andradina, Dourados, respectively, all in the state of Mato Grosso do Sul.

At the beginning of the development of the actions, participatory meetings were held with the target group to make the initial decisions such as the definition of the demonstration area, implementation planning, and development of activities. The settlers

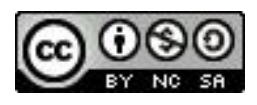


received guidance every month, with theoretical and practical explanations on how to deal with bees and about obtaining good quality the honey.

Each settlement had different times with the beginning of the extension project. Some older settlements the project started in 2008, while others like the Arreias settlement the extension project started in 2015.

As beekeeping was considered a secondary activity, there was a concern to take into account the characteristics of each community. After the formation of the groups, the area available for setting up the apiary and the labor available in each settlement were evaluated to adjust the number of swarms appropriate for each community, always concerned with the wellbeing of bees and producers.

For the development of beekeeping activities, what was called the "Beekeeping Kit" was acquired, which consisted of recycled wood and consumable material for the manufacture of nests, honey boxes, lids, backgrounds, pictures, easels and other complementary materials for the beekeeping practice. To expand the apiaries, swarms were captured, which were housed in termites, roofs, dry trunks, and other places considered to be at risk, for people and bees.

After the end of the first year of capturing the bees, the production of each box began to be recorded, so that at the end of the harvest (spring-autumn), the total production of the honey produced would be recorded.

\section{RESULTS AND DISCUSSION}

The implementation of beekeeping practices in the settlements came as a source of extra income since in the Areias and Quilombola Community settlements the main activity was organic horticulture and in the Santa Rosa, Itamarati, and Santa Olga settlements, it was milk production. This factor has a direct effect on the number of swarms and honey production (Table 1), as producers dived your time on other activities.

It can be mentioned that the honey collection is correlated with the incidence of rain that has a direct effect on the flowering in the different regions, which implies in different periods of beginning and ending of collections (PEREIRA et al., 2006), in addition, to directly influence the production of honey, since the settlements are located in different regions, thus influencing the availability of food for the swarm.

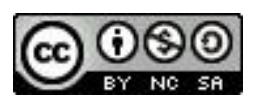


Table 1. Distribution of swarms and honey production in the settlements for the 2019 harvest

Settlement Number of families Number of swarms Honey production $(\mathrm{kg})$

\begin{tabular}{lccc}
\hline Arreias & 26 & 18 & 200 \\
Comunidade & 3 & 18 & 300 \\
Quilombola & 7 & 30 & 1500 \\
Santa Rosa & 12 & 18 & 650 \\
Itamarati & 8 & 16 & 220 \\
Santa Olga & 4 & 40 & 2400 \\
Amparo & & & \\
\hline
\end{tabular}

In the Areias settlement, due to the location of the apiary (Figure 1), high wetland, the quality of the honey collected was considered good, due to the wide variety of flowering present in the place, however low honey production $(200 \mathrm{~kg})$ was observed when compared years ago when production reached around $800 \mathrm{~kg}$. The low amount of honey harvested in the 2019 harvest can be explained due to the low commitment of some producers with previous years, thus influencing the inadequate and deficient handling of the swarms causing losses.

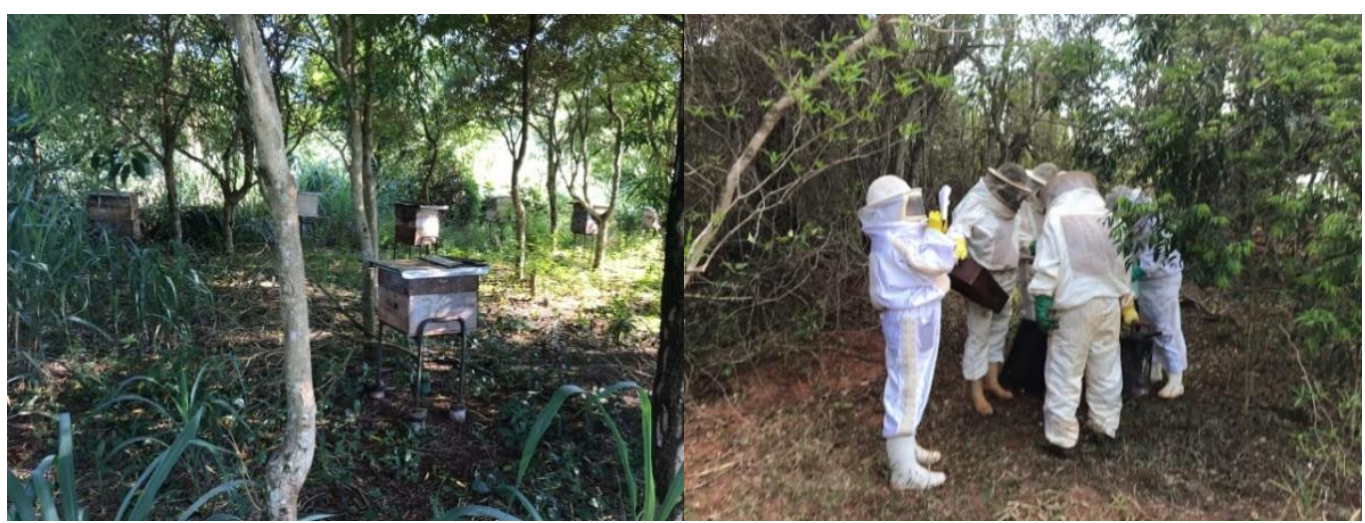

Figure 1. Apiary, Areias Settlement, Nioaque city, MS

The group's activities in the Areias settlement are returning, with the formation of new leadership and the aggregation of new participants, and the group currently has 26 families, farmers. The strong leadership found in this group increases the commitment of

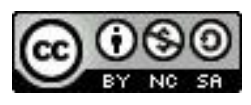


the other members, resulting in an organized group, with a greater division of tasks, making all participants in the group feel important and motivated (PIRES, 2002).

The group of producers in the Quilombola community had motivating actions to improve the locations of the apiaries, to carry out hive junctions as well as to increase their production, since they do not have many areas available for the assembly of other apiaries. The growth of beekeeping in the settlement was through the increase in the number of honey boxes per box combined with the proper management of queens, that is, growth in a vertical way. Currently the group is composed of three families, using 18 boxes with 60 honey boxes (Figure 2).

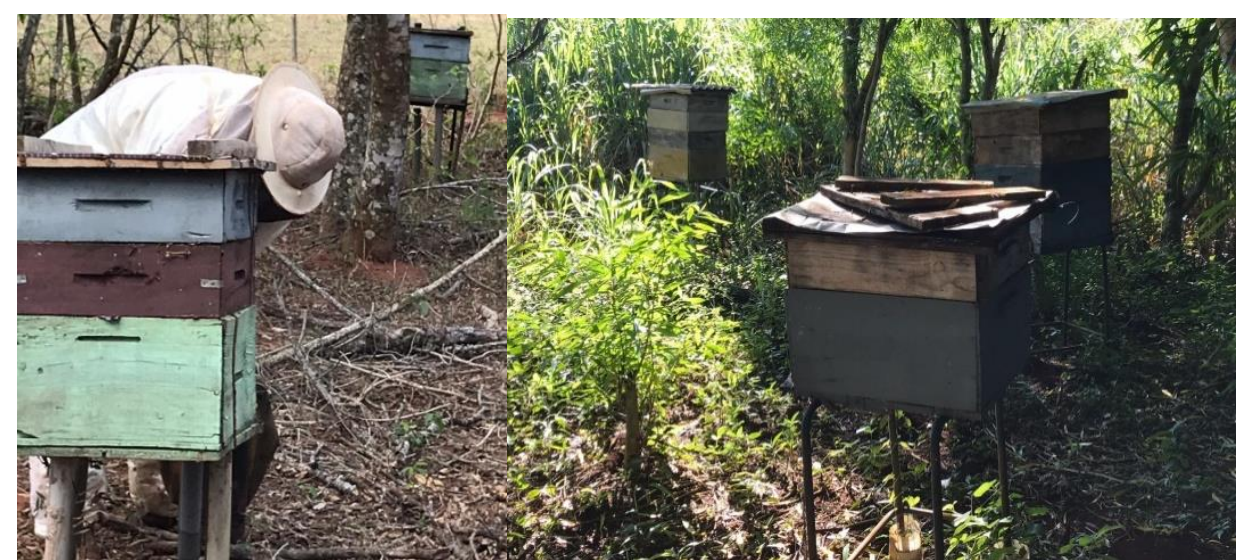

Figure 1. Apiary, Quilombola Settlement, Municipality of Dourados, MS

Because the Quilombola community is close to the city of Dourados, this group of producers had to receive guidance aimed at the safety of apiaries to avoid accidents. To guarantee the quality of the honey, equipment was purchased, such as smoker, chisel, brush/broom dusting comb, uncapping (fork), uncapping table, bee attire (overalls, mask, glove, and boots), decanter tank.

Currently, in the Santa Rosa settlement, the group is composed of seven participants who develop the activity using 30 boxes with swarms, however, it was observed that the group has great potential to increase its production due to the strong leadership and the commitment of the group participants in the development of the activities. It is important to emphasize the importance of people with a proactive profile and willingness to learn and continue activities (OLIVEIRA, 2006). The product obtained was $1500 \mathrm{~kg}$ per harvest, which may increase production in the coming years.

For the assembly of the Apiary of the Itamarati settlement, the group was guided on the items that should be respected for the correct location of the bees on the site.

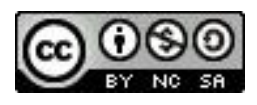


Currently the group responsible for the apiary in the Itamarati is formed by 12 families and works with 20 boxes with 3 to 4 watermelons per box. The group has a very strong organization and relies on the honey home. Production in 2019 averaged $60 \mathrm{~kg}$ of honey per swarm, making a total of $650 \mathrm{~kg}$.

In the Santa Olga settlement, production in other years reached a peak of $300 \mathrm{~kg}$ of honey per harvest and in May $2019220 \mathrm{~kg}$ of honey was collected from 16 hives, part of which was destined for own consumption and the rest, about $186 \mathrm{~kg}$, were processed for commercialization. The sale of part of the product proved to be an important source of extra income for the group of eight families. There was also the effect of group work that demonstrated the best interaction between those involved, awakening the sense of togetherness.

Currently, the Amparo settlement group consists of four families. The group has 40 swarms and uses about 120 melgueiras (Figure 3). Improvements have been made in the apiary to build a centrifuge room, a place that was made available for those involved in the action to process the collected honey, which is in line with the expansion of activities already carried out and under development. The average production of honey per box in the 2019 harvest was $60 \mathrm{~kg}$.

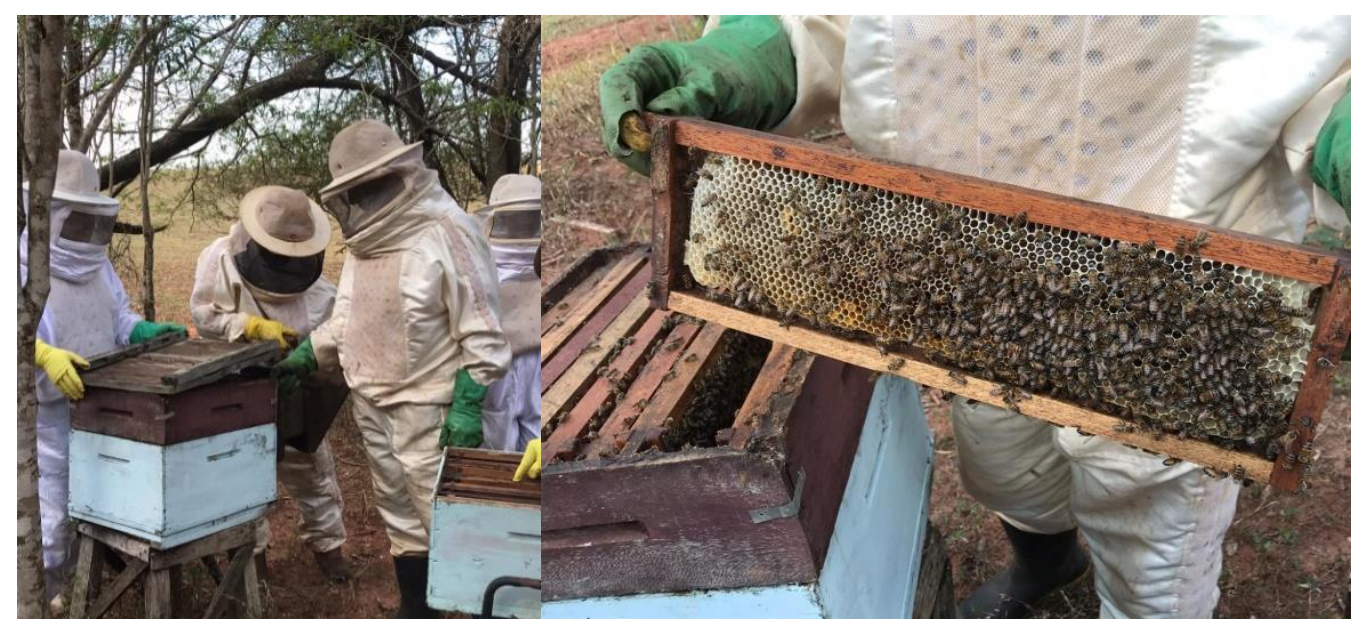

Figure 3. Honey collection and swarm revision management at the Amparo

Settlement, Dourados, MS

The centrifugation room acquired by the group is intended to facilitate the processing of honey, to avoid bees in homes, since honey was processed at night in the producers' homes, putting family members at risk processing done in all settlements mentioned in the present work. Thus, this acquisition was of paramount importance, since in addition to ensuring security for beekeepers, it also influences the quality of the final

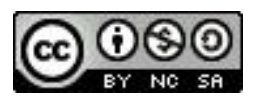


product (honey); because the centrifugation process makes the appropriate separation of honey, maintaining its natural formation, and not altering its viscosity, its shelf life (DA COSTA et al., 2005).

Another activity worth mentioning was the implementation of an apicultural forest installed around the apiary and the centrifugation room to improve the bee pasture and protection against the effects of the winds.

It is observed that, despite the particularities found in the settlements, beekeeping came as a way of diversifying the activities of the settlers, not only being considered as a source of extra income for families but also as an important source of supplementation for food. of them, due to the beneficial properties of honey, such as being a food rich in energy and in countless other substances beneficial to the balance of the biological processes of the organism, especially amino acids, enzymes, vitamins, and phenolic substances, as mentioned by CAMARGO et al. (2006) and SILVA et al. (2006).

Activity diversification has become an important strategy for small farmers to improve the condition and quality of life of their families, managing to stay in the countryside (BARBOSA et al., 2016). The improvement in the families' quality of life was measured through their reports.

\section{CONCLUSION}

The results showed that beekeeping can be a viable activity, guaranteeing extra income for small producers, especially when there is adequate technical guidance, thus showing the importance of rural extension as a way of guiding small producers.

\section{ACKNOWLEDGMENTS}

To the National Council for Scientific and Technological Development (CNPq), and the Coordination for the Improvement of Higher Education Personnel (CAPES) for granting a scholarship. Support from the Federal University of Grande Dourados, through the Dean of Extension and Culture (PROEX / UFGD); to the Technological Vocational Center in Agroecology and Organic Production, in Mato Grosso do Sul and to the Nucleus of participative construction of knowledge in agroecology and organic production at UFGD.

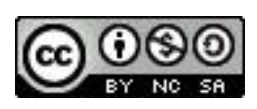




\section{REFERENCES}

BARBOSA, P. J. F., MENDONÇA, J. C. A., CASAROTTO, E. L., MACHADO, R. R., DE ALMEIDA, V. L., VITORINO FILHO, V. A. A importância da diversificação agrícola como complemento na renda familiar na região de Manhuaçu-MG. Revista do CCEI, v. 20, n35, p. 1-11. 2016.

BLUM, C. T.; OLIVEIRA, R. de F. Reserva Florestal Legal no Paraná, alternativas de recuperação e utilização sustentável. SEMINÁRIO NACIONAL DEGRADAÇÃO E RECUPERAÇÃO AMBIENTAL-perspectiva social, Foz do Iguaçu, 2003.

CAMARGO, R. C. R.; PEREIRA, F.M.; LOPES, M. T. R.; WOLFF, L. F. Mel: características e propriedades. 21 ed. Teresina: Embrapa Meio-Norte, 2006.

DA COSTA, C. C., PEREIRA, R. G., PRATA FILHO, D. D. A. Influência de centrífuga no processamento do mel de abelha. Engenharia Agrícola, v.25, n. 3, p. 809-816, 2005.

KRONEMBERGER, T.S.; GUEDES, C.A.M. Desenvolvimento territorial rural com gestão social: um estudo exploratório entre Brasil e Argentina. Organizações Rurais \& Agroindustriais, v. 16, n. 2, p. 233-246, 2014.

MUNGUIA, M. A. Apicultura mexicana, mercado mundial de miel y problemática ambiental; un enfoque prospectivo. México: Educe Y Paual., 1998.

OLIVEIRA, E. R.; MONÇÃO, F. P., RAMOS, M. B. M., GABRIEL, A. M. A., FARIAS, M. D. F. L., MOURA, L. V. Práticas extensionistas no desenvolvimento sustentável da comunidade quilombola de Dourados, Mato Grosso do Sul. Em Extensão, v. 11, n. 2, 2012.

OLIVEIRA, M. D. L. S. Mulheres na liderança, relações de gênero e empoderamento de Reforma Agrária: o caso do Saco do Rio Preto em Minas Gerais. Tese (Doutorado). Universidade Federal Rural do Rio de Janeiro, 2006.

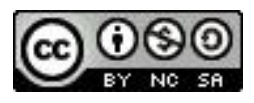


PEREIRA, F. D. M., FREITAS, B. M., ALVES, J. E., DE CAMARGO, R. C. R., LOPES, M. D. R., VIEIRA NETO, J. M., \& ROCHA, R. S. Flora apícola no Nordeste. Embrapa Meio-Norte-Documentos (INFOTECA-E). 2006.

PIRES, M. A. Diagnóstico sócio-econômico de Assentamentos rurais na região de Ponta Porá e as perspectivas de desenvolvimento local. Tese de Doutorado. Dissertação de Mestrado, Universidade Católica Dom Bosco, Campo Grande. 2002.

SANCHEZ, R. O. Apicultura no Cerrado. Goiânia (GO); Editora Kelps. P. 92, 1997.

SILVA, R. A.; MAIA, G. A.; SOUSA, P. H. M.; COSTA, J. M. C. Composição e propriedades terapêuticas do mel de abelha. Alimentos e Nutrição, v. 17, n. 1, p. 113$120,2006$.

VIEIRA, G. H. da C.; SILVA, R. F. R.; GRANDE, J. P. Uso da Apicultura como Fonte Alternativa de Renda para Pequenos e Médios Produtores da Região do Bolsão, MS. In: $2^{\circ}$ CONGRESSO BRASILEIRO DE EXTENSÃO UNIVERSITÁRIA, Belo HorizonteMG.Anais...v.1.p. 1-7. 2004 